\title{
The Character Development Defense to the Argument from Evil Is Logically Inconsistent
}

\author{
Randall S. Firestone \\ Department of Philosophy, El Camino College, Torrance, CA, USA \\ Email: Randyfirestone@verizon.net
}

How to cite this paper: Firestone, R. S. (2018). The Character Development Defense to the Argument from Evil Is Logically Inconsistent. Open Journal of Philosophy, 8, 444-465.

https://doi.org/10.4236/ojpp.2018.85031

Received: September 8, 2018

Accepted: September 26, 2018

Published: September 29, 2018

Copyright $\odot 2018$ by author and Scientific Research Publishing Inc. This work is licensed under the Creative Commons Attribution International License (CC BY 4.0).

http://creativecommons.org/licenses/by/4.0/

\begin{abstract}
The Argument from Evil is usually considered the strongest argument against the belief in the Judeo-Christian conception of a perfect God. It states that a perfectly good, omniscient, and omnipotent God would not allow the degree of evil which exists in the world. This paper describes why the theist's strongest response to this argument, widely known as the Soul-Making Theodicy and which this paper calls the Character Development Defense, rests on a logical contradiction. The argument proffered here reformulates an earlier argument made by B.C. Johnson which has been largely ignored in the philosophical literature. Specifically, the Character Development Defense asks humans to develop their character and thereby to take moral actions which benefit others, including mankind as a whole, but at the same time states that we need all the suffering in the world in order to give us ample opportunities for character development. If we follow the logic of this defense to its conclusion, then we should both help others to improve the world, but also not help them because that takes away the opportunities people need to develop their characters. This paper also reviews the literature in this area so it can be seen how the current argument takes a quite different approach. Lastly, the paper addresses five possible objections, and then replies to each objection.
\end{abstract}

\section{Keywords}

Soul-Making Theodicy, Soul-Making Defense, Response to the Soul-Making Defense, Logical Inconsistency of the Soul-Making Defense, Best-of-All-Possible Worlds, Problem of Evil, Character Development Defense, Argument from Evil 


\section{Introduction}

The Argument from Evil is usually considered the strongest argument against the belief in the Judeo-Christian conception of a perfect God. It states that a perfectly good, omniscient, and omnipotent God would not allow the degree of evil which exists in the world. In this paper I will describe why the theist's strongest response to this argument, the theodicy ${ }^{1} \mathrm{I}_{\text {call the Character De- }}$ velopment Defense and which is widely known as the Soul-Making Theodicy, rests on a logical contradiction that is apparent on the face of the argument.

Most prior attacks on the Character Development Defense show that it cannot hold up to the empirical evidence of how the world actually functions. The argument proffered here, however, presents a different and more fundamental criticism by reformulating an earlier argument made by B.C. Johnson which has been largely ignored in the philosophical literature, namely, that this theodicy is a non-starter because it is logically inconsistent or self-contradictory. Before turning to the argument, I will review the literature in this area so we can see how the argument I set forth is different. After making my argument, I will address five possible objections.

\section{The Argument from Evil}

One common version of The Argument from Evil proceeds as follows:

1) There is a lot of evil, misery, and suffering in the world.

2) An omnipotent, omniscient, and all-good God would not allow so much evil, misery, and suffering.

3) Therefore, such a God does not exist.

By evil the argument refers to both natural evils and moral evils. Natural evils include the harm caused by diseases, viruses, plagues, famine, natural disasters, the predation of animals, accidents, etc. Moral evils include the evil actions done by human beings, such as torture, slavery, fighting, selfishness, the deaths, injuries, starvation and homelessness due to war, and the mental and emotional cruelty humans inflict on one another. In the history of our species, the combination of these two have resulted in difficult if not miserable lives for the majority of human beings, and have further caused the premature deaths of a significant proportion of the people born on earth-with a large percentage of people dying

${ }^{1}$ Joel Tierno explains the difference between a defense to the Argument from Evil and a theodicy about evil as follows: "In the context of the problem of evil, a defense differs from a theodicy in that a defense is only intended to maintain the logical coherence of the central claims of theism. To offer a defense is to offer a logically possible explanation of evil, or a particular evil, within the creation of God. The goal is to avoid the definitive refutation of theism. The aim of a theodicy, on the other hand, is to endorse the truth or bolster the reasonableness of theism. To offer a theodicy is to endeavor a rationally convincing explanation of evil, or a particular evil, within the creation of God. The burden of a theodicy, then, is much greater than the burden of a defense." (Tierno, 2006: p. 167). As it turns out, a theodicy provides a stronger defense than a "mere" defense as it provides real reasons or evidence to believe its assertions instead of just remote and even strained possibilities which may not be realistic. Having noted this, it is clear that a theodicy is one type of defense. 
as children, often suffering a painful death. ${ }^{2}$

On a common sense level, if there were a perfect God, why would God create a world where its inhabitants kill and eat each other, where viruses and bacteria debilitate and exterminate its higher beings, where natural disasters wipe out whole villages of good people, and where in the past so many mothers suffered and then died in childbirth-robbing many young women of their lives and so many children of their mothers? This is quite puzzling as it does not seem that an all-loving creator would create such a world.

As David Hume pointed out, if the effect is imperfect then we are not warranted to assume that the cause is perfect:

For as the cause ought only to be proportioned to the effect... You have no reason, on your theory, for ascribing perfection to the Deity... or for supposing him free from every error, mistake, or incoherence in his undertakings. There are many inexplicable difficulties in the works of Nature... (Hume, 1779: pp. 41-42)

Therefore, if the world is an imperfect place, as it appears to be, then we can only justifiably assume that if it had a creator, the creator is similarly imperfect.

We can further help motivate the argument with a drowning baby example. Let us suppose that unbeknownst to his parents, a baby boy has gotten out of his house and crawled down the block and into a shallow puddle of water. The baby's arms have slipped so that he is now drowning in the water. A stranger close to the puddle sees the baby drowning, and could easily pick the baby up and thereby save the baby without any danger to himself. Nobody else is present in the street. The stranger feels, however, that the baby is of no concern to him so he lets the baby drown. What would we think of such a person? I think the answer is obvious. We would not only consider the stranger to be immoral, but we would likely conclude that he is a moral monster. What normal human being would not save the baby under these circumstances?

The argument continues that God seems to be in the same position as the

${ }^{2}$ David Hume described what is meant by evil, misery, and suffering as follows: "A perpetual war is kindled amongst all living creatures. Necessity, hunger, want, stimulate the strong and courageous: Fear, anxiety, terror agitate the weak and infirm. The first entrance into life gives anguish to the newborn infant and to its wretched parent: Weakness, impotence, distress, attend each stage of that life: and it is at last finished in agony and horror... The stronger prey upon the weaker, and keep them in perpetual terror and anxiety... Consider that innumerable race of insects, which either are bred on the body of each animal, or flying about infix their stings in him... every animal is surrounded by enemies, which incessantly seek his misery and destruction... Man is the greatest enemy of man. Oppression, injustice, contempt, contumely, violence, sedition, war, calumny, treachery, fraud; by these they mutually torment each other... How many lie under the lingering torment of diseases?... Remorse, shame, anguish, rage, disappointment, anxiety, fear, dejection, despair; who has passed through life without these tormentors?... Were a stranger to drop, on a sudden, into this world, I would show him, as a specimen of its ills, a hospital full of diseases, a prison crowded with malefactors and debtors, a field of battle strewed with carcases, a fleet foundering in the ocean, a nation languishing under tyranny, famine, or pestilence... Not satisfied with life, afraid of death" (Hume, 1779: Part X, pp. 70-73). Alvin Plantinga sums this up nicely: "In addition to 'natural' evils such as earthquakes, tidal waves, and virulent diseases there are evils that result from human stupidity, arrogance, and cruelty.” (Plantinga, 1974: p. 8) 
stranger. So many people, including children, are suffering and dying in the world every day, but God lets them suffer and die, as did the stranger in our example. If there were an omniscient God then he would know that many innocent people are suffering and dying. If this God were also omnipotent then he would be able to save these people. Lastly, if God were all-good then he would want to save these people. The fact that so many innocent people continue to regularly suffer and die indicates that no such God exists.

Similarly, J. L. Schellenberg argues that one who has experienced and truly understands horrific suffering, which a perfect God would understand due to having experienced it from the inside, would want to minimize or eliminate such suffering. As such, God would not have actualized our world with all of its horrific suffering. Therefore, we should not believe that a perfect God exists. ${ }^{3}$

\section{The Theodicy Defenses}

Long ago, Saint Augustine of Hippo (354-430), Saint Thomas Aquinas (1225-1274), and the German philosopher Gottfried Leibniz (1646-1716) pointed to a possible solution to the Argument from Evil. They explained that evil may serve a greater good or higher purpose that would both make it worth having and of which an all-good and perfect God would approve. Leibniz stated that "we do not desire these evils, but we are willing to permit them for the sake of a greater good which we cannot reasonably help preferring to other considerations."

Philosophers have identified two "greater goods" which allegedly explain why some amount of evil, and even a great amount of evil, should be preferred to a world which contained little to no evil. These provide the basis of the two most noteworthy theodicies or theistic responses to the Argument from Evil, such as the ones developed by Alvin Plantinga and John Hick, ${ }^{5}$ called the Free Will Defense and the Best of All-Possible-Worlds or Soul-Making Theodicy, the latter of which I will call the Character Development Defense. ${ }^{6}$ It should be kept in mind that the two defenses are probably best considered together as one complete defense or theodicy which presents a story of why God might allow so much evil in the world. The separation into two separate defenses, however, has the advan-

\footnotetext{
${ }^{3}$ Schellenberg argues as follows: "Therefore, taking stock of our human cases, it appears we can say that the greater someone's empathy (i.e. the greater their compassion and the deeper and fuller their acquaintance with horrific suffering), the stronger is their opposition to horrific suffering-their disposition to seek to eliminate and prevent it wherever they can. But God would, if existent, be maximally empathetic (maximally compassionate and maximally well-acquainted from every vantage point, and in particular from the inside, with every instance of the horrific going on somewhere in our world at virtually every moment). So what should prevent us from drawing the conclusion that God would, if existent, be maximally opposed to the existence of all this suffering, and thus maximally opposed to actualizing our world?" (Schellenberg, 2007: p. 247)

${ }^{4}$ Leibniz, G., 1710: p. 146.

${ }^{5}$ See Hick, 1966 and Plantinga, 1974.

${ }^{6}$ There are certainly other theodicies or defenses which this paper will not be addressing. For example, another theodicy claims that God allows men to suffer as punishment for their sins. Stump has argued that this produces an inconsistency similar to the one I will argue exists in the Character Development Defense, namely, it appears I should not help others if their suffering is deserved due to their sins, but one of the fundamental tenets of Christianity and most religions is that we should help others in need (see Stump, 1983: p. 58, note 4).
} 
tage of allowing for easier conceptualization and analysis.

The Free Will Defense asserts that God gave us the valuable gift of free will-which is the ability to do otherwise than our genetics and experiences would indicate. We are not similar to a computer, a plant, or an ant which do not seem to be able to act contrary to their programming or instincts. Indeed, those who believe in free will claim that our actions are not determined by our past and our bodily makeup, and as such our actions could not be predicted even if someone had perfect knowledge of everything about us. It is our apparent ability to say "no" to acting as we have in the past that gives us the ability to change and even reverse the direction of our lives, and as such we are responsible for our actions. ${ }^{7}$

The Free Will Defense goes on to assert that with free will necessarily comes both morally good actions and morally bad actions, but this is still good because without free will we would not be the creative, moral, and responsible creatures which we are capable of being. As such, the moral evil in the world, which is a necessary consequence of the exercise of human free will, is overall good. ${ }^{8}$

However, given all of the suffering that our free will has caused to others, one might justifiably wonder if it is really worth our having it. Moreover, the Free Will Defense accounts, at best, for only a relatively small proportion of the suffering in the world. This is because the amount of moral evil, the evil committed by human beings, pales in comparison to natural evil, such as the numerous diseases and sicknesses caused by viruses, bacteria, parasites, and insects which have caused so many humans to suffer and/or die. For these reasons most theists believe that we need to supplement and buttress the Free Will Defense with an additional defense, what I call the Character Development Defense.

The Character Development Defense argues that it is plausible that God's primary concern for human beings is not our temporary happiness on earth; rather, God may well place a priority on the development of good moral character-which includes both developing ourselves internally and also taking actions which helps others. ${ }^{9}$ John Hick explains as follows:

\footnotetext{
${ }^{7}$ In a previous paper, I defined free will as follows: "It is the view that at least some conscious decisions a person or agent makes is decided by them and not by the many external and internal influences which act upon them. This type of free will is non-random in the sense that each decision unambiguously flows from the agent and does not just randomly occur for no reason at all and with no clear genesis or source. The agent is the author or source. It is the agent who chooses from among competing desires, instincts, habits, motivations, personal character and personality traits, and other mental states-even if that choice is to let one's instincts or desires run their course. This means as to the decision made, the agent could have chosen otherwise than they did. Although the decision can be and normally is influenced by both internal and external factors, these factors do not cause the actual decision that was made—-the agent does." (Firestone, 2017: p. 65)

${ }^{8}$ Alvin Plantinga sets forth a similar description of the Free Will Defense (see Plantinga, 1974: p. 30).

${ }^{9} \mathrm{Hick}$ explains that the mere overcoming of personal temptation or of developing empathy and sympathy is not enough without also engaging in morally good actions: "The value-judgment that is implicitly being invoked here is that one who has attained to goodness by meeting and eventually mastering temptations, and thus by rightly making responsible choices in concrete situations, is good in a richer and more valuable sense than would be one created ab initio in a state either of innocence or virtue. In the former case, which is that of the actual moral achievements of mankind, the individual's goodness has within it the strength of temptation overcome, a stability based on the accumulation of right choices, and a positive and responsible character that comes from the investment of costly personal effort." (emphasis added) (Hick, 1966: pp. 255-256)
} 
Men are not to be thought of on the analogy of animal pets, whose life is as agreeable as possible, but rather on the analogy of human children, who are to grow to adulthood in an environment whose primary and overriding purpose is not immediate pleasure but the realizing of the most valuable potentialities of human personality...Certainly we seek pleasure for our children, and take great delight in obtaining it for them; but we do not desire for them unalloyed pleasure at the expense of their growth in such even greater values as moral integrity, unselfishness, compassion, courage, humour, reverence for truth, and perhaps above all the capacity for love. We do not act on the premise that pleasure is the supreme end of life... Rather, this world must be a place of soul-making. (Hick, 1966: pp. 258-259)

One especially effective way to develop moral character is to have evil, misery, and suffering in the world. This gives each person the opportunity they need to both develop empathy, sympathy, and compassion and also to act courageously and benevolently. This theodicy continues that we need just the amount of evil, misery, and suffering that we have in the world. Any less evil would not give us enough opportunities to develop our character, and any more would cause excessive suffering which would not serve the higher purpose of character development and would be inconsistent with an all-good God. ${ }^{10}$ So the Character Development Defense admits that there is a lot of evil, misery, and suffering in the world, but it asserts that our world has the perfect amount so as to give us adequate opportunities for character development.

We should emphasize that the Character Development Defense recognizes that suffering would be excessive if it did not serve the higher purpose of character development. Malcolm Murray explains this point:

Consider first, the worry about why there is so much suffering-so much so, that it often incapacitates us, overwhelms us, as opposed to invigorates us. When the degree of suffering is more than we can psychologically handle, no beneficial effects on us can be expected... If suffering were designed purely for our benefit, God would ensure that the suffering were not so excessive as to wipe out its good effects. (Murray, 2010: p. 108)

Incorporating the two defenses together, the theodicies assert that God may have given us free will to develop good moral character; we need a lot of evil,

\footnotetext{
${ }^{10}$ Stephen Maitzen points out that not all suffering is good for the sufferer-implying that the suffering would be excessive if it did not aid in soul development. He states that "we ordinarily recognize an obligation to prevent suffering at least partly because we presume that suffering often produces no net benefit for the sufferer..." (Maitzen, 2009: p. 113). Even the Christian apologist Richard Swinburne admits that although "God has the right to allow humans to cause each other to suffer, there must be a limit to the amount of suffering which he has the right to allow a human to suffer for the sake of a great good." (Swinburne, 1996: p. 214) Swinburne, however, concludes that since our lives are finite and people need not suffer for over 80 years or so, then any amount of suffering in this life is justified-presumably because they will thereafter exist forever in Heaven. Besides having to assume that Heaven exists, another metaphysical assumption which is not testable or provable, it seems to me that future happiness cannot adequately justify years of prior torture and suffering that need not have occurred.
} 
misery, and suffering to develop that character; and natural evil, such as tornadoes, hurricanes, and diseases contribute to the evil and suffering, and as do immoral human actions. Ironically, the evil, misery, and suffering are overall good because they give people ample opportunities to take actions which will alleviate that suffering. All in all, we have the perfect amount of good and evil, and of pleasure and suffering in the world, just what we would expect from a perfect creator.

\section{Responses to the Free Will and Character Development Defenses}

There have been many responses, which I will quickly outline here, to both of the theist's defenses. ${ }^{11}$

Initially we should notice that we have to assume that humans have free will or else both the Free Will and Character Development defenses make no sense at all. I have elsewhere argued for the position that we do have free will, ${ }^{12}$ and for purposes of this article let us assume that we do, but it should be noted that many if not most neuroscientists and philosophers do not believe that we $\mathrm{do}^{13}$ and, further, J. L. Schellenberg has made a strong case that the world and human lives would be better if we did not have free will (see Schellenberg, 2007: Chapter 13, pp. 270-290).

Others have argued against the Free Will Defense by stating that we could have free will, but still have a lot less evil, misery, and suffering in the world. At least six ways exist in which God could have tweaked humanity or been more active in our lives in order to lessen the prevalence or impact of evil.

First, God could have given us limited free will. For example, an all-powerful God could have made it so we would never desire to torture, severely injure, or kill other human beings. Since most of us never seek to do such things, most people would act no differently than they currently act, but such a limitation would greatly limit the amount of evil, misery, and suffering in the world. ${ }^{14}$

Second, God could have created us with more natural empathy, sympathy, and compassion so that we would be less likely to harm others. It would seem a tweaking of our genetics could accomplish this. We would still have free will, but would be less likely to do morally bad things, including and especially really bad things.

Third, God could have made us less susceptible to diseases and injuries so that

${ }^{11}$ Most of these arguments can be found in the Stanford Encyclopedia of Philosophy under the heading “The Problem of Evil." Edward Madden and Peter Hare (Madden \& Hare, 1968) have also made many of these points.

${ }^{12}$ See Firestone, (2017).

${ }^{13}$ A survey conducted in November 2009 by PhilPapers of 1803 philosophy faculty members or PhDs and of 829 philosophy graduate students found that only $13.7 \%$ accepted or leaned toward libertarian free will (PhilPapers, 2009).

${ }^{14}$ Malcolm Murray makes this point as follows: "So, it is possible to make people free in some respects—say, in choosing a career, a spouse, one's friends, a hobby-and yet, not be free in other matters: say, having a desire to hurt someone. In other words, it's a false dichotomy to say that either we are fully free or that we are fully automatons. There is so much room in between." (Murray, 2010: p. 105) 
we would be less likely to suffer and/or prematurely die.

Fourth, God could have created a greater abundance of renewable natural resources, which would tend to make us less selfish and thereby we would be less likely to cause harm to others.

Fifth, God could make his presence and teachings absolutely clear, including the consequences for our actions, and give us clear personal guidance, much as a good parent gives to their children. Although we would have free will, it seems that if we had such clear and unmistakable guidance we would be more likely to act in a moral manner.

Sixth, God could intervene in history more often to stop the worst evils from occurring. Louis Pojman made this point as follows: "If, by the mere pressing of a button, I could have caused Hitler to have had a heart attack before starting WWII, I would have been obliged to do so. Why did God not intervene in 1939 and prevent the evil of World War II, including the Holocaust?" (Pojman, 2001: p. 75). Indeed, since Hitler was responsible for the deaths of tens of millions of innocent people, it seems God's intervention would have made the world a much better place and still preserved our free will. One would expect that a good God would want to do so.

In all of the above cases, we would have free will, but there would be a lot less evil, misery, and suffering in the world. It certainly seems that an all-good God, if such a god exists, would support and manifest these changes or actions.

As to the Character Development Defense, there are two leading interrelated responses that have been advanced. The first response argues that there would be sufficient opportunities for character development even with a lot less evil in the world, and the second response asserts that some of the evil in the world does not contribute to character development at all and, as such, there is unnecessary evil in the world which is inconsistent with an all-good and perfect God.

As to the first point, many people believe that there could be a lot less evil, misery, and suffering and still be plenty of opportunities remaining for character development. This is supported by the fact that evil, misery, and suffering are not now evenly distributed in the world, nor have they been evenly distributed when comparing different eras. For example, we have much less evil, misery, and suffering in modern-day America than is present in many modern-day African and Middle Eastern nations where wars and diseases have resulted in not only many deaths, but also in many displaced, homeless, injured, diseased, and starving people. Similarly, when we compare different eras we see that the average American today lives a much healthier and longer life than most people did in earlier times. ${ }^{15}$

\footnotetext{
${ }^{15}$ Further, we should not neglect that even within any given country, the amount of evil, misery, and suffering experienced has been grossly unequal between different people. Virtually every country has people who have lived lavish lifestyles and faced few hardships in their lives compared to the severe hardships suffered by others. We can safely assume that some wealthy people have led insulated lives where they have neither been adequately exposed to nor fully appreciated the extreme suffering that so many other people in the world endure-even people in their own country. This may have been especially true in the past before the advent of modern communications technology. Their opportunities for character development were quite limited and even miniscule compared to what many other people have faced.
} 
Certainly, if the relatively minor amount of evil and suffering that most Americans experience today is sufficient, then we could have had a lot less evil, misery, and suffering in earlier times and in many third world countries today. This seems especially true since it appears that in some places and times the amount of evil, misery, and suffering is so severe that instead of fostering character development it undoubtedly has encouraged immoral actions. Edward Madden and Peter Hare make this point as follows:

One must remember that while unjust suffering may increase compassion, it also creates massive resentment. This resentment often causes individuals to indiscriminately lash out at the world. The benefits of compassion are probably more than offset by the damage done by resentment. (Madden \& Hare, 1968: p. 159)

In fact, Stanley Kane has argued that it is dubious whether evil is needed at all to develop good character. He reasoned that one could develop courage, fortitude, and compassion by engaging in difficult tasks and supporting others who are doing so. ${ }^{16}$

Even if Kane overstates his case, it seems to many people that there could be a lot less evil, misery, and suffering in the world even if there is a God whose primary desire for us is to develop our character. In further support of this point, Eleonore Stump claims that all natural evil is unneeded because there seems to be enough moral evil present to give humans an abundance of opportunities to meaningfully exercise their free will. She cites as an example the Nazi World War II Concentration Camp Belsen where 70,000 people were exterminated.

Belsen was entirely the work of man's hand, and evils of that magnitude with the serious choices they entail are still possible even if God prevented all hurricanes, earthquakes, mental retardation, birth defects, and so on... God could fail to prevent all major (natural) evils, thus leaving man serious choices and a serious choice of destiny, simply by failing to prevent all major man-made evils, those for which man rather than God is responsible. And so it is not necessary for God to allow natural evils to occur in order to give man serious choices. (Stump, 1983: p. 57)

The second response to the Character Development Defense is that there

${ }^{16}$ Kane argues as follows: "Soul-making, Hick teaches, requires the development of such traits as fortitude, courage, compassion. This, we are told, justifies the existence of many evils, since-according to his theodicy-these evils are a logically necessary condition for the development of such traits. This last claim, however, can be challenged. We can imagine situations where these traits could be displayed even though there is no actual evil existing. Courage and fortitude, for instance, could manifest themselves as the persistence, steadfastness, and perseverance it takes to accomplish well any difficult or demanding long-range task-the writing of a doctoral dissertation, for example, or training for and competing in the Olympic Games. Tasks like these take the same sort of strength of character, the same sort of persistence in the face of difficult obstacles, that is required to endure nobly the suffering of disease, natural disasters and similar sorts of adversity. Compassion could be evidenced in the sympathy and fellow-feeling that a person could show for someone engaged in one of these long-range enterprises and in all that he might do to help the person complete his task." (Kane, 1975: p. 2) 
seems to be unnecessary evil in the world which does not aid at all in character development. If we could find even one instance of unnecessary evil in the entire history of the world, then the Character Development Defense fails because God would not be all-good if God allowed any evil which did not serve the higher purpose of character development.

Three examples support this response. First, William Rowe has given us the story of a fawn who suffers terribly as it is burned alive in a forest fire. ${ }^{17}$ Let us assume that the fawn had no living relatives and that no other animal or person witnessed its death nor ever learned of the fawn's death. In such a case, it does not seem that the fawn's death aided in anyone's soul or character development, and thus this would be a case of unnecessary evil which served no higher purpose and was therefore inconsistent with a perfect all-good and all-powerful God.

Second, Marilyn McCord Adams has pointed out that there seems to be horrendous evils that are so severe that those who suffer those evils would not and do not consider their own lives to be a good or even worth living. She lists a few of such evils: "the rape of a woman and the axing off of her arms, psycho-physical torture whose ultimate goal is the disintegration of personality, betrayal of one's deepest loyalties, child abuse of the sort described by Ivan Karamazov, child pornography, parental incest, slow death by starvation, the explosion of nuclear bombs over populated areas." (McCord Adams, 1999: p. 26)

Indeed, in at least some cases of horrendous evils, one would expect that for the recipient of the evil there can be no realistic expectation of developing a healthy and moral character. The horrors in their lives are so overwhelming that they impede instead of foster moral development. Louis Pojman sums up this point as follows:

Why could God not aid us in our soul building without resorting to horrendous evils, perhaps in the way that astronauts are trained? A good teacher can educate and help build character without resorting to torture and brutality. (Pojman, 2001: p. 75)

Moreover, as J.L. Schellenberg points out, since some people supposedly are able to attain heaven without horrific suffering, such suffering appears unnecessary for character development. ${ }^{18}$

The third example is part of a devastating critique on the theist defenses to the Argument from Evil offered by Gregory Paul. Paul uses a statistical analysis and shows that the majority of fetuses and fully half of all children have died before reaching maturity-and therefore before they had the opportunity to maturely

\footnotetext{
${ }^{17}$ See Rowe, 1979.

${ }^{18}$ Schellenberg explains as follows: "But if there can be persons capable of experiencing the deepest good available to them even where there is no horrific suffering, who could be justified in permitting such suffering. Who, while perfectly empathetic, would permit it?... Just try to conceive of a God whose empathy is unimaginably greater than that of your mother or of Mother Teresa permitting children to slowly burn to death, experiencing with them each moment of their horror, when everyone including those children can achieve not only very great goods but even their deepest good without the permission of such suffering." (Schellenberg, 2007: pp. 248, 249)
} 
exercise their free will and develop their moral character. ${ }^{19}$ According to his calculations, only 1 out of 8 human conceptions survive to adulthood. Paul summarizes his points as follows:

Of the hundreds of billions of human conceptions, the large majority died before birth, over half the one hundred billion born have died as children, a portion of the survivors were severely harmed, and among children the great majority suffered high and even extreme levels of discomfort, pain, and fear that qualifies as torture. This dysfunctional system can be objectively described as merciless or ruthless...And if countless billions of immature people suffer and die too young, then they never get to express their free will in the first place. (Paul, 2009: pp. 132, 141)

Indeed, Paul has pointed out that the majority of human conceptions end in the suffering and death of the fetus or person before they have had the opportunity to exercise their free will and thereby develop their character, and as such, these two theistic defenses cannot apply to them.

\section{The Character Development Defense Is Logically Inconsistent}

The preceding responses to the Character Development or Soul-Making Defense utilize evidence obtained from the world. They argue that when we look at the world we see that there is excessive evil, misery and suffering beyond what is necessary to develop our characters, and/or that some suffering, a portion of which are horrendous evils, do not result in the development of good and moral character. This is where most of the work on this topic rests. What has been largely overlooked, and what I aim to show in this section, is that the Character Development Defense is logically inconsistent and hence can be shown, a priori, to be untenable without even appealing to specific facts about the world. ${ }^{20}$

The Character Development Defense asserts that the reason there is so much evil, misery, and suffering in the world is to give us adequate and ample opportunities to develop and exhibit good moral character-which includes as a major component that of helping others. However, once we perform good actions and improve the world and the beings in it, then we have taken away from others the opportunities they need to develop good moral character. As such, it seems that we should not try to help others. So the Character Development Defense seems to imply two conflicting duties: the duty to reduce evil and suffering, and the

\footnotetext{
${ }^{19}$ Specifically, Paul cites studies which indicate that $75 \%$ of all conceptions have ended in miscarriage and that throughout history $2 / 3$ of pre-adult deaths have occurred to children under 5 years old (Paul, 2009: p. 128).

${ }^{20}$ Philosophers have raised inconsistencies in the Character Development Defense which I will not be addressing. G. Stanley Kane, for example, raises several paradoxes within the argument (see Kane, 1975). Stephen Maitzen has offered a strong argument for the position that the evil in the world is logically inconsistent with our ordinary notions of morality. His argument is quite similar to mine and although I support the thrust of Maitzen's argument, I think that my argument has the advantage of not needing to appeal to any principles that the Character Development Defense does not explicitly endorse (see Maitzen, 2009: p. 108).
} 
duty not to reduce evil and suffering.

A similar argument was made by B.C. Johnson, though it has been largely neglected in the literature. This may be in part because Johnson couched his argument in stronger terms than is necessary. Johnson argues as follows:

[W] should note that God is represented as one who tolerates disasters, such as infants burning to death, in order to create moral urgency. It follows that God approves of these disasters as a means to encourage the creation of moral urgency. Furthermore, if there were no such disasters occurring, God would have to see to it that they occur. If it so happened that we lived in a world in which babies never perished in burning houses, God would be morally obliged to take an active hand in setting the fire to houses with infants in them...

All of this is of course absurd. If I see an opportunity to create otherwise nonexistent opportunities for moral urgency by burning an infant or two, then I should not do so. But if it is good to maximize moral urgency, then I should do so. (Johnson, 1981: p. 102)

So Johnson argues that the Character Development Defense requires that we both try to improve the world and minimize "moral urgency" while at the same time we should harm others, such as "by burning an infant or two", and thereby adding evil, misery and suffering into the world in order to provide moral urgency. ${ }^{21}$ While I have argued that the Character Development Defense is inconsistent as it requires us to both help others and also to not help others, Johnson makes the stronger assertion that the argument requires us to help others and also to harm others.

Why would Johnson claim that the Character Development Defense requires us to actively create moral urgency by intentionally harming others and not merely by avoiding helping them? I think the answer is that one could plausibly argue as follows: In a world filled with technological and medical advances which are significantly bettering most people's lives, the only way to give people ample opportunities for character development is for some of us to, at least at times, intentionally decide to harm others-and then to harm them.

One might respond to Johnson by claiming that perhaps intentionally engaging in immoral actions is not needed. For all one knows, if we were to merely refuse, at times, to help others, there might be sufficient evil to provide ample opportunities for character development. So perhaps we may not need to intentionally harm others.

In any event, if we think about this we can see that the Character Development Defense puts each of us in an impossible situation. We would need to help others in order to develop our character, but also at times refuse to help others (or perhaps even harm them) so that there would be adequate opportunities to develop character.

${ }^{21}$ Johnson uses "moral urgency" to mean evil or bad situations which provide opportunities for moral action. 
Moreover, as the world as a whole now appears to be much better for humans than in past times, should all of us, at least for a time, stop helping others in order to restore enough evil, misery, and suffering in the world so that character development can flourish? But if we do so, then we directly contradict the Character Development Defense which instructs us to help others.

Another way to approach the paradox is to notice that when I do what is best for my own character development by helping others, I am often not doing what is best for the character development of others. As such, it seems that a perfect God would not want me to develop my character by doing good deeds if it is at the expense of others who would not then be afforded adequate opportunities for their own character development, but yet, the Character Development Defense seems to demand that I do help others.

Johnson argued that it is certainly the morally right thing to help others, but if this is true then the Character Development Defense stands on collapsing grounds because it appears to encourage us, at a minimum, to ensure that the opportunities for character development not be taken away or unduly limited, and/or, at a maximum, to actively harm others and create additional moral urgency in the world. Johnson points out the inconsistency of the argument as follows:

It is worthwhile to emphasize, however, that we encourage efforts to eliminate evils; we approve of efforts to promote peace, prevent famine, and wipe out disease. In other words, we do value a world with fewer or (if possible) no opportunities for the development of virtue (when "virtue" is understood to mean the reduction of suffering). If we produce such a world for succeeding generations, how will they develop virtues? Without war, disease, and famine, they will not be virtuous. Should we cease our attempts to wipe out war, disease, and famine? If we do not believe that it is right to cease attempts at improving the world, then by implication we admit that virtue-building is not an excuse for God to permit disasters. (Johnson, 1981: p. 103)

We are left with a paradox: On the one hand we should try to significantly better the world and its inhabitants, while at the same time we should not try to do so.

\section{Five Objections and Replies}

The following five theistic objections attempt to show how God's presumed desire that we have adequate opportunities to develop good moral character can be consistent with our doing good things that take away future opportunities from ourselves and others. These objections set forth and frame the Character Development Defense in a way to make the inconsistency go away by arguing that for various reasons our help will not appreciably or significantly affect or alter the amount of evil, misery, and suffering in the world. However, Objection 5 suffers from its own inconsistency, while Objections 1 - 4 argue for facts which are con- 
trary to how the world actually operates. As such, the first four objections are proposing counterfactuals that contradict reality and thus should not be taken seriously. We will see that all five objections are unable to resolve the self-contradictory nature of the Character Development Defense.

\subsection{Objection 1: The Equilibrium Argument Based on Moral Evil}

This objection asserts that any decrease in evil, misery, and suffering caused by some people's beneficial and moral actions will be counterbalanced by a corresponding increase in evil caused by other people. Indeed, one might want to claim that although some people are working to lessen the amount of evil, misery, and suffering, there will always be other people who are acting immorally and thus keeping the overall amount of such suffering at the same level.

Unfortunately, this argument seems to be no more than wishful thinking because no such equilibrium can be guaranteed if people really do have free will. People can use their free will to make things better or to make things worse, and there is no reason to believe that the amount of evil, misery, and suffering in the world will not and cannot significantly vary in different places and in different times-as it clearly has.

Indeed, it follows that if God gave us free will, then God gave each person the ability to choose to act morally or immorally, and there would be no way to accurately predict or know how many persons will act one way or another. In fact, when we look at the world, we instantly see this is true, as when it comes to moral evils committed by humans, some places have much less evil, misery, and suffering than other places, and some eras have endured much more suffering than other eras. This is what one would expect with the exercise of free will.

Furthermore, it has now been well-documented that the amount of moral evil in the world has been steadily decreasing. Steven Pinker has done an extensive statistical analysis which shows that the rate of all types of human-created violence, including deaths as a result of homicides and war, have been substantially decreasing as time goes on. He sums up his conclusion as follows:

Believe it or not-and I know that most people do not-violence has declined over long stretches of time, and today we may be living in the most peaceable era in our species' existence. (Pinker, 2011: Preface xxi)

We now know that native peoples, whose lives are so romanticized in today's children's books, had rates of death from warfare that were greater than those of our world wars. The romantic visions of medieval Europe omit the exquisitely crafted instruments of torture and are innocent of the thirtyfold greater risk of murder in those times. The centuries for which people are nostalgic were times in which the wife of an adulterer could have her nose cut off, children as young as eight could be hanged for property crimes, a prisoner's family could be charged for easement of irons, a witch could be sawn in half, and a sailor could be flogged to a pulp. The moral commonplaces of our age, such as that slavery, war, and torture are wrong, 
would have been seen as saccharine sentimentality, and our notion of universal rights almost incoherent... But for all the benefits that modernity has brought us in health, experience, and knowledge, we can add its role in the reduction of violence. (Pinker, 2011: pp. 693-694)

We can conclude that not only would we not expect that when some people help others there will necessarily be others who will harm others to the same degree, but the evidence in our world indicates that there is much less moral evil in the world today than in past times.

\subsection{Objection 2: The Equilibrium Argument Based on Natural Evil}

This objection claims that any decrease in evil, misery, and suffering caused by some people's good and moral actions will be counterbalanced by a corresponding increase in natural evil.

Although theoretically possible, when we look at the history of the world we see that this has not been the case. In fact, today the richer industrialized countries enjoy much lesser amounts of moral evil without any corresponding increase in natural evil. If we look at people who lived in the past century in the United States, the quality and length of their lives significantly increased without any noticeable uptick in natural disasters, diseases, or other natural evils. These people clearly had fewer opportunities to develop good moral character as they faced much less adversity than people who had lived in prior times. This objection is simply at odds with the empirical facts.

\subsection{Objection 3: The Equilibrium Argument Based on Divine Intervention}

One might retort that the first two objections were needlessly too weak in that of course we would not expect people to always offset the good deeds of some by doing a substantially similar number of bad deeds of the same magnitude and effect, and further, of course we cannot reasonably expect that the blind forces of nature which are not conscious in themselves would know when to increase natural disasters and diseases and then act accordingly. For this we would need a conscious being to intervene in the world such as God-which brings us to our next objection.

The theist could claim that God wants humans to develop our character by doing good deeds, and that God himself will ensure that there is enough evil, misery, and suffering in the world by God's own interventions. For example, if God sees that humans are creating a world free of many diseases, God could create new diseases, or if humans are constructing a more peaceful world, God could stir things up by putting misleading thoughts in people's minds so that more wars will occur. God could make sure that the most skilled peacemakers die, or that the minds of the best scientists become enfeebled such as by the early onset of dementia. God could intervene in nature by producing more natural disasters such as devastating hurricanes or tsunamis, or could have it rain less 
and create severe drought conditions, or could mutate insects to be pesticide-resistant so that they would devastate much of our cropland. If so, humans can help others and need not be concerned with supplementing the evil either by sometimes harming or at times refusing to help others.

In other words, the conflict drops out because we have our role, namely, the development of our character, and God has his role, namely, to create enough evil to give us ample opportunities for character development.

However, we again see that when we examine the empirical evidence it does not bear out the claim that there is a God who has added evil, misery, and suffering into the world in an amount which counterbalances the substantial good people have done in recent times which has significantly improved the lives of most people living in the world-especially in the advanced first world countries. Indeed, it is obvious that no God has ensured the proper equilibrium of the amount of evil, misery, and suffering in the world, and no God has negated the progress that humans have made which has bettered so many people's lives. Disasters have not significantly increased in the past 200 years to make up for our numerous advances in technology and medicine, nor have a greater percentage of people acted immorally to balance out the good that has been added to the world.

\subsection{Objection 4: The Range Argument}

This objection contends that there is a permissible range of evil, misery, and suffering and, further, that the moral actions of one or more people will not eliminate so much suffering so that there will not be adequate opportunities for character development. A theist could cite the fact that most suffering in the world is the result of natural causes and not human causes. Human actions account for only a relatively small amount of the differences in evil, misery, and suffering in different places and times. Moreover, because free will is a good thing for humans to have, God can and must allow some variance in the amount of evil, misery, and suffering in the world; however, this variance is always within a permissible range which preserves enough evil, misery, and suffering so that there is invariably enough to give each person ample opportunities to develop good moral character. As such, human beings can strive for moral excellence and to improve the world and still not inhibit God's plan to provide numerous opportunities for soul development.

Facts collected by Gregory Paul support this argument. ${ }^{22}$ Paul has pointed out that historically the great majority of fetal and childhood deaths have not been the result of human actions or moral evil, but instead have been the result of natural evil, such as microbial diseases like malaria, smallpox, typhoid, scarlet fever, or the plague. Specifically, Paul explains that all of the wars of the last century, which resulted in far more war deaths than in any prior centuries, accounted for maybe 150 million deaths. Although that is certainly a lot of people,

\footnotetext{
${ }^{22}$ See Paul, 2009.
} 
there were 10 billion people born during that time. Therefore, wars only killed about $1.5 \%$ of the people who had been born and were living in the last century. Paul concludes that human actions have accounted for a very small percentage of the overall evil, misery, and suffering in the world.

As such, it could be argued that as long as suffering caused by humans is relatively small compared to the suffering caused by natural evil, including the natural evil of death due to old age, human actions will have little overall effect on the amount of evil and suffering available for character development.

This argument fails, however, for several reasons. The amount of morally good human actions can and has significantly improved the world by limiting or remediating the effects of not only moral evil, but also of natural evil, and paradoxically, the effects of morally bad human actions in the future may well greatly increase the amount of suffering on earth. In either case, the amount of suffering has not in the present and past and would not in the future fall within any acceptable range of suffering. We can look at 4 variables to see this: Morally good actions, morally bad actions, the past and the future.

First, past (though relatively recent) morally good human actions have eliminated or limited not only a substantial amount of the moral evil done by humans, but also have successfully prevented much of the natural evil in the world. Specifically, human medical advancements have eliminated or successfully treated so many diseases and have helped heal so many injuries that today there has been a substantial reduction in the amount of evil, misery, and suffering in much of the world compared to earlier times. Paul concludes that "in the last century and a half, the number of unborn and children saved from an early death by adults using modern technologies is a few billion." (Paul, 2009: p. 129). This is graphically demonstrated by the increase in life expectancy. It has been estimated that until Medieval times human life expectancy worldwide was between 20 and 35 years old, but presently is about 71.5 years, and in the modern democratic first world countries is closer to 80 years. Therefore, in the past few hundred years-a relatively short amount of time in the existence of our species, worldwide life expectancy has more than doubled.

Furthermore, the moral actions of a relatively few human beings have been quite successful in eliminating enormous amounts of human suffering. For example, Sir Alexander Fleming is known for the invention of the antibiotic substance penicillin, which has been used to treat countless ailments, including scarlet fever, pneumonia, strep throat, and blood poisoning. It has been estimated that up to 200 million human lives have been saved due to penicillin. Similarly, Jonas Salk was the first person to discover the antidote to polio, a disease that had crippled millions of people, especially children. Likewise, in the $1800 \mathrm{~s}$ tuberculosis was responsible for almost 25\% of all deaths in Europe, but following the first successful immunization in 1906 by Albert Calmette and Camille Guerin coupled with better sanitation, the tuberculosis death rate in Europe and in the United States is now negligible. According to the Character Development 
Defense, the actions of these medical scientists have thwarted God's will to give humans enough suffering so as to have adequate opportunities to develop good moral character.

Indeed, human actions have given the great majority of people living today substantially better lives compared to most human lives in earlier eras. Pinker poignantly makes this point:

These defenses of modernity recount the trials of daily living before the advent of affluence and technology. Our ancestors, they remind us, were infested with lice and parasites and lived above cellars heaped with their own feces. Food was bland, monotonous, and intermittent. Health care consisted of the doctor's saw and the dentist's pliers. Both sexes labored from sunrise to sundown, whereupon they were plunged into darkness. Winter meant months of hunger, boredom, and gnawing loneliness in snowbound farmhouses.

But it was not just mundane physical comforts that our ancestors did without. It was also the higher and nobler things in life, such as knowledge, beauty, and human connection. Until recently, most people never traveled more than a few miles from their place of birth. Everyone was ignorant of the vastness of the cosmos, the prehistory of civilization, the genealogy of living things, the genetic code, the microscopic world, and the constituents of matter and life. Musical recordings, affordable books, instant news of the world, reproductions of great art, and filmed dramas were inconceivable, let alone available in a tool that can fit in a shirt pocket. When children emigrated, their parents might never see them again, or hear their voices, or meet their grandchildren. And then there are modernity's gifts of life itself: the additional decades of existence, the mothers who live to see their newborns, the children who survive their first years on earth. (Pinker, 2011: p.

As such, it seems that either the amount of suffering in the past was quite excessive, or the substantially lesser amount of suffering today is quite insufficient. In either event, the suffering in past and present times is so radically different that they certainly fall within significantly different ranges.

Second, morally good human actions in the future can be expected to eliminate or remediate substantially more human suffering. In fact, scientists now expect that genetic and other medical breakthroughs will lead to the prevention and successful treatment of most diseases. If we assume that we needed the amount of suffering which existed in past times, then such a future would surely take us out of the permissible range of suffering which would ensure adequate opportunities for the development of good moral character.

Third, we can look at human morally bad actions in the past and see that in many places those actions have caused there to be such extensive suffering that character development was surely discouraged rather than encouraged. As such, 
at least in many places, it seems pretty clear that there has been excessive suffering due to human cruelty that has been well beyond the permissible range of suffering.

Fourth, it is ironic that even though human actions have so significantly reduced human suffering so that for most people in the world today there are much fewer opportunities for character development, the opposite may be true in the future. In fact, it is quite possible that in the future human morally bad actions will account for most of the evil, misery, and suffering in the world and thereby trump the amount of natural evil in the world. This would certainly be the case if only a few of the many apocalyptic predictions come true. For example, a large-scale nuclear war would directly kill millions or even billions of people and, further, make this world virtually unlivable for any survivors due to the radioactive fallout and the resulting nuclear clouds which would block sunlight and make it difficult to grow crops. Human moral evil could also make this world a miserable place to live if we do not avoid the future dangers of pollution and global warming-which are predicted to make the air unbreathable and fresh water unavailable to many if not most people, in addition to the rising seas that are expected to kill thousands if not millions and also to displace billions of people. Indeed, we can see that it is quite possible that human actions will not only cause the lion's share of future evil, misery, and suffering, but human actions may also greatly magnify the suffering to such a horrible level that it will be well beyond what is necessary for the development of good moral character-and in fact counterproductively discourage moral development and encourage moral depravity if humans are competing with others for survival in a nightmarish world.

Indeed today, even with all the modern medical and technological advancements that have so significantly improved so many peoples' lives, it still seems that the amount of evil, misery, and suffering in many countries and in many places is well beyond any reasonable range, or alternatively, the relative absence of significant evil, misery, and suffering in some countries and in some places is below the range necessary to provide sufficient opportunities for character development.

\subsection{Objection 5: The Divine "Satisficing" Argument}

This objection maintains that an imperfect world is consistent with a perfect God if the world is "good enough." The assertion is that a perfect God could allow there to be an imperfect amount of evil, misery, and suffering in the world. Specifically, the argument claims that the varying amounts of evil, misery, and suffering in the world are "good enough." In other words, God is still perfect if he creates an overall good world. Although he could have created a better one, this creation is "good enough." This has been labeled as God "satisficing"-God sufficiently satisfies his perfection even by creating an imperfect world.

However, it seems to me that "good enough" only gets us a "good enough" 
God, not the Judeo-Christian perfect one. If God could make this a better world and chooses not to, then God does not seem to be all-good.

The theist still must demonstrate that this is the best of all possible worlds, for if it is not, then any deities may be considered great or powerful, but not perfectly good and just. Klaas Kraay makes this point as follows:

God is not merely supposed to be excellent, or superior, in goodness and rationality; God is taken as essentially unsurpassable in these and other respects...Moreover, even if such arguments would succeed in establishing the rational or moral permissibility of divine satisficing, this would not be enough: further work would still be needed to show that satisficing is consistent with essential divine unsurpassability... "Good enough" is just not good enough for God. (Kraay, 2013: pp. 404, 405)

It appears that satisficing is inconsistent with a perfect God, and hence this reply suffers from the same problem that the Character Development Defense suffers from-it is logically inconsistent. Thus, this reply is of little help to the theist.

\section{Conclusion}

If the substantially lesser amount of evil, misery, and suffering in much of the world today is adequate for character development, then God has allowed there to be too much in the past and therefore God is not all-good or all-powerful. If, on the other hand, we do not have adequate opportunities today, then God's will is being thwarted by man's moral actions which have successfully bettered this world. The Character Development Defense asks humans to develop their character and thereby to take moral actions which benefit others, including mankind as a whole, but at the same time states that we need all the suffering in the world in order to give us ample opportunities for character development. If we follow the logic of this defense to its conclusion, then we should both help others to improve the world, but also not help them because that takes away the opportunities people need to develop their characters. This contradiction demonstrates the failure of the Character Development Defense and shows that the problem of evil remains an intractable problem for the theist. It may be that the perfect God of the Judeo-Christian tradition simply cannot be intelligibly defended in the face of the often horrendous, certainly abundant, and seemingly superfluous amount of evil, misery, and suffering that has been present in the past and still persists in many parts of the world today. ${ }^{23}$

\footnotetext{
${ }^{23}$ We should note that the Character Development Defense attempts to deal with the Argument from Evil by appealing to this world, i.e., humans need to develop their characters in our lifetimes on earth. Another type of solution has been proposed by Marilyn McCord Adams. She concedes that some horrendous evils cannot be compensated for or justified by any amount of earthly goods-even the good of character development. Her theodicy appeals to transcendental goods (goods not of this world) such as the unsurpassable goodness of a relationship with God that one will experience in Heaven. This is a very different sort of argument that is unrelated to my paper. I think it has its own significant problems, but this is a topic for another time (see McCord Adams, 1999).
} 


\section{Conflicts of Interest}

The author declares no conflicts of interest regarding the publication of this paper.

\section{References}

Firestone, R. (2017). An Argument for Libertarian Free Will: Hard Choices Based on either Incomparable or Equally Persuasive Reasons. Open Journal of Philosophy, 7, 64-93. https://doi.org/10.4236/ojpp.2017.71005

Hick, J. (1966). Evil and the God of Love. New York: Palgrave MacMillan.

Hume, D. (1779). Dialogues Concerning Natural Religion (2006 ed.). New York: Barnes \& Noble.

Johnson, B. C. (1981). The Atheist Debater's Handbook. New York: Prometheus Books.

Kane, G. S. (1975). The Failure of Soul-Making Theodicy. International Journal for Philosophy of Religion, 6, 1-22. https://doi.org/10.1007/BF00136996

Kraay, K. (2013). Can God Satisfice? American Philosophical Quarterly, 50, 399-410.

Leibniz, G. (1710). The Theodicy: Abridgement of the Argument Reduced to Syllogistic Form. In L. Pojman (Ed.), Philosophy of Religion, an Anthology (4th ed., pp. 146-151). Belmont, CA: Wadsworth/Thomson Learning.

Madden, E., \& Hare, P. (1968). Evil and the Concept of God. Springfield, Illinois: Charles C. Thomas. In L. Pojman (Ed.), Philosophy of Religion, an Anthology (4th ed., pp. 156-159). Belmont, CA: Wadsworth/Thomson Learning.

Maitzen, S. (2009). Ordinary Morality Implies Atheism. European Journal for Philosophy of Religion, 2, 107-126. https://doi.org/10.24204/ejpr.v1i2.343

McCord Adams, M. (1999). Horrendous Evils and the Goodness of God. Ithaca: Cornell University Press.

Murray, M. (2010). The Atheist's Primer. Peterborough, Ontario: Broadview Press.

Paul, G. (2009). Theodicy's Problem: A Statistical Look at the Holocaust of the Children, and the Implications of Natural Evil for the Free Will and Best of All Worlds Hypotheses. Philosophy \& Theology, 19, 125-149. https://doi.org/10.5840/philtheol2007191/27

PhilPapers (2009). http://philpapers.org/surveys.

Pinker, S. (2011). The Better Angels of our Nature: Why Violence Has Declined. New York: Penguin Books.

Plantinga, A. (1974). God, Freedom, and Evil. Grand Rapids, MI: William B. Eerdmans Publishing Company.

Pojman, L. (2001). Philosophy of Religion. Long Grove, IL: Waveland Press, Inc.

Rowe, W. (1979). The Problem of Evil and Some Varieties of Atheism. American Philosophical Quarterly, 16, 335-341.

Schellenberg, J. L. (2007). The Wisdom to Doubt: A Justification of Religious Skepticism. Ithaca, NY: Cornell University Press.

Stanford Encyclopedia of Philosophy. The Problem of Evil.

Stump, E. (1983). Knowledge, Freedom and the Problem of Evil. International Journal for Philosophy of Religion, 14, 49-58. https://doi.org/10.1007/BF00136952

Swinburne, R. (1996). Is There a God? In S. Cahn (Ed.), The World of Philosophy (2nd 
ed., pp. 209-217). New York: Oxford University Press.

Tierno, J. (2006). On Defense as Opposed to Theodicy. International Journal of Philosophy of Religion, 59, 167-174. https://doi.org/10.1007/s11153-006-8326-Z 